\title{
PRECARIZATION OF WORK AND MIGRATION: A REVIEW OF THE INTERNATIONAL LITERATURE
}

\author{
Guilherme Primo Matias, Gabrielle Ribeiro Rodrigues da Silva, Fabio Emanuel Farago ${ }^{1}$ \\ Universidade Federal do Paraná - UFPR, Paraná, (Brasil) \\ Universidade de São Paulo - USP, São Paulo, (Brasil)
}

\section{ARTICLE DETAILS}

\section{Article history:}

Received: 15 February 2019

Accepted: 01 November 2019

Available online January: 01 th 2020

\section{Double Blind Review System}

\section{Scientific Editor}

Ilan Avrichir

\section{Key words}

Precarious work

Migration process

Precarization

Worker

Systematic review

\begin{abstract}
Objective: This research aims to highlight the relation between precarization of work and migration, based on the understanding that migrant workers take part assisting in the economic and social development of the countries.

Method: The methodology used was a systematic review of the international literature on precarious work and migration in the period from 2008 to 2018.

Main results: People migrate between countries for economic, social or political factors. Common of these three reasons is the desire to have a better life conditions. Even in some cases these migrants get access to benefits, they probably will suffer some kind of precariousness - whether in unhealthy services, without legal protection or living in unsuitable housing. This is the ambivalent nature of the precarious work - and its consequences.

Relevance/originality: It is observed that large part of the research on migration in the least developed countries began with propositions borrowed from researchers who codified the experience of developed countries. It is necessary in our field to present a systematic examination of how precarization and migration are addressed in the organizational studies.

Theoretical/Methodological Contributions: As a contribution to the field, in this paper it is proposed a theoretical model that involves the two phenomena and, provides the reader with standardized and systematic scientific information that may assist in the development of the field by mapping existing knowledge on this subject.
\end{abstract}

\section{INTRODUCTION}

The focus of scientific studies on the precarious work has increased in recent decades, especially since 1970 (Kalleberg, 2012). Therefore the issue of work insecurity has emerged as a challenge and a concern in the world (Kalleberg \& Hewison, 2013). The advances of globalization have manifested in an intense way, mainly through the increase of competitiveness in the markets, the reduction of wages, the increase of informal work and also the reduction of the number of job vacancies due to the automation.

All these factors contribute to forcing workers to accept what is imposed on them because they prefer to have the minimum conditions for survival and work towards capitalism and maximize private profit (Hirst \& Thompson, 1998). Thus, discussions about the implications of precarious work remain hesitant and often confusing (Campbell \& Price, 2016). Faced with this, proletarian workers often have their basic needs and minimum rights uncertain, in a precarious way (Alves, 2007).

The precarious work transforms previously safe environments into insecure, unstable and arduous places for workers (Kalleberg, 2009). Furthermore, the precarious work may manifest itself in different ways and among them there are informality, lack of worker protection, low-income distribution and the forced integration of the population into capitalist labor relations (Chang, 2009).

In this consonant, Massey (1993) shows that many emerging countries have become diverse and multiethnic societies and that countries which are not yet in these conditions are moving in that direction.

${ }^{1}$ Contact of the author Email: fabio.farago@hotmail.com 
Migratory processes present themselves as a basic structural characteristic of industrialized countries. Nevertheless, the migrant worker is the one who leaves a place of origin towards a place of destination and is motivated by several factors caused by a major progress in globalization (Golgher, 2004).

Although the precarious work is present to all workers and in different situations, the most alarming is the one faced by migrant workers (Hobson \& Bede, 2015). The effects of globalization on markets and the competitiveness have shown changes in the migratory flows in different countries and, in this process, migrant workers are often victims of precarious work environments (Lima \& Martins, 2012). The precarious work according to Campbell, Boese and Tham (2016) tends to occur broadly among migrants and is centered on low remuneration, violation and/or lack of labor legislations, illegal practices, and is facilitated mainly by informal work.

Nevertheless, without neglecting the significant role of labor mobility in socioeconomic development and planning in Third World countries, it should be noted that scientific knowledge about the nature of migration still lacks detail. It is observed that large part of the research on migration in the least developed countries began with propositions borrowed from researchers who codified the experience of developed countries (Arthur, 1991).

It is necessary in our field to present a systematic examination of how precarization and migration are addressed in the organizational studies. Thus, this research emphasizes the relation between the precarization of work and the migration, based on the understanding that migrant workers take part in assisting in the economic and social development of the countries (Mcdowell, Batnitzky \& Dyer, 2009). However, they still suffer in precarious work environments and that area still needs to be better explored.

In two stages the international database Web of Science was used to find articles that related the terms "precarious work"; "migration"; "precarious*"; "work*"; "labor" and "migra*", in the period from 2008 to 2018. As a contribution to the field, in this paper it is proposed a theoretical model that involves the two phenomena and, provides the reader with standardized and systematic scientific information that may assist in the development of the field by mapping existing knowledge on this subject. This research was structured in five parts: this introduction; the theoretical framework on precarization of work and migration processes; the methodological procedures; the discussion of the findings; and finally, the final considerations followed by the references used.

\section{PRECARIZATION OF WORK}

The precarious work has emerged in the literature as a dominant concept in critical studies on labor and labor relations (Betti, 2016). The concept of precariousness is broad and ranges from the themes of technological change, flexibilization, restructuring, legislation and insecurity in the precarious work (Strauss, 2017). Currently, studies of this issue in contemporary society may be considered as a growing field due to the advancement of the effects of globalization of production in the neoliberal era and discuss several terms as insecurity at work, precariousness, the worker precariousness and precarious work (Arnold \& Bongiovi, 2013).

The precarious work is evident from the beginning of the capitalist system. However, its most recent phase began in the 1970s (Arnold \& Bongiovi, 2013). In this period, the growth of the effects of globalization and the quest for economic development combined with the oil crisis (19731974) increased global competition for better prices. This fact forced producers from different countries to become more competitive in order to survive (Kalleberg, 2009).

Moreover, global competition and technological advances have increased. As a result, these factors have led to the flexibilization of labor contracts, generating outsourcing of labor, low wages, and amplifying migration processes which resulted in the expansion of precarious work (Kalleberg, 2012).

Labor relation and social inequality have been successfully put on the research agenda by historians, archaeologists, institutional (historical) economists, political scientists, and sociologists. Historical demography, comparative historical life-course studies, and migration history have all added greatly to our understanding of the ways in which people have tried to improve their situation and climb the social ladder (Bresser- Pereira, 2015).

It is emphasized that depending on the context, the precariousness of the work is seen through different lenses. Kalleberg and Hewison (2013) point out that for European researchers the theme is often 
seen as the loss of social rights, of protections to the worker, through the flexibility of work. In Asian countries, the issue is tackled as a norm, which ends up in making it less relevant. Antunes and Praun (2015) reveal that in the Latin context, thanks to neoliberal actions and, as a result, the restructuring imposed by these policies, the flexibilization of labor contracts and the increase of informal jobs further deepen the effects of precarious work in the life of the proletariat.

The causes of precarization may be explained mainly by the growth of informal work, the absence of laws and norms that assure and protect the worker, the economic expansion that is not accompanied by a balanced income distribution and by the forced integration of the population in capitalist labor relations - which involves mass migration (Chang, 2009). Workers in capitalist systems are open to the demands of the market, often without proper institutional protection. Both the state and the syndicates, which in theory should protect the worker, are in practice increasingly assisting in the development of precarious work (Arnold \& Bongiovi, 2013).

Changing economic structures have influenced labor relations (Lucassen, 2016). Studies involving the precarious work deal fundamentally with the prevalence of contingent and flexible work - caused by neoliberalism - in our society (Neilson \& Rossiter, 2008). It is emphasized that precariousness is not voluntary; in the world of flexible form of labor relations, the proletarian class ends up being forced to submit to the precarious work. This occurs due to the fact that people need work to meet the basic needs of a physiological nature and safety, and for this, they need financial compensation, even if unjust and in a precarious work environment (Lá Botie, 2015). In this context of an uneven nature, freedom of the working individual is not complete, but is forged in disguised servitude (Alves, 2007). These transformations of neoliberal economy have costs that may be summarised by the widespread phenomena of burnout (Paltrinieri, 2017).

The precarious work becomes a source of vulnerability and anguish both individual and social, and affects both the family of the precarious individual and their housing and community security (Wilson \& Ebert, 2013). In addition, when it comes to the gender roles in the family, females tend to have more precarious jobs, which means that they are more likely to have work of doubtful quality, have less laws that protect them as well as the benefits and financial return (Young, 2010). As one may perceive, there is a large disadvantage of the female gender in relation to the male gender.

Beyond that, precarious work and the precariousness of the worker may result in chronic diseases (Kim et al., 2008). That is, the individual in a precarious working environment may develop chronic musculoskeletal disorders and liver diseases. Having said that, the females tend to suffer more from health problems than the males. In addition, in the quest for the transfer of costs to workers through the flexibilization of work, organizations end up generating precarization and relying on the normative deficiencies imposed by the public power (Wilson \& Ebert, 2013). They implement strategies to reduce costs of transaction which, however, contributes to precarious work.

\section{The Migration Process}

The migration debate has oscillated as a pendulum: from the developmental optimism of the 1950s and 1960s to neo-Marxist pessimism in the 1970s and 1980s, and toward more optimistic views in the 1990s and 2000s (De Haas, 2010). However, the concept of migration includes a number of factors about the place of origin and destination, intervening obstacles and personal characteristics. Variations in the volume of migration are related to the diversity of the regions and the population that inhabit it, the degree of difficulty of the intervening obstacles and the fluctuations of the economy (Lee, 1966).

Lee (1966) indicates that migration may be defined as a permanent or semi-permanent change of residence. Salim (1992) points out that the migration process involves multiple movements continuous, intermittent or circular - that imply permanent and temporary changes, or, more specifically, simple labor mobility.

Golgher (2004) concludes that the individual leaving a region is an emigrant from his or her place of origin. However, what comes to a region is an immigrant at his destination. As a result, migrants may be motivated by higher expected returns abroad if better outcomes between skills and jobs are realized (Nekby, 2006).

When a person changes his place of residence, he changes his life and also causes changes, even if slight, in the places where he emigrated and where 
he immigrated. Thus, the consequences of migration may be studied from both a personal and a regional point of view. The migrant evaluates the gains and losses that the process of change brings (Vera \& Alves, 1985). Even though migration may bring a lot of costs to everyone involved, as personal or financial, it may be interpreted as a new source of jobs and a better quality of life (Sabot, 2019). In this statement, one may infer that the reasons for moving to another country might be based on economic, social or political reasons.

Migration acts as a transformation agent, translated into a set of social relations, and is retained to enable the analysis of concrete forms of workforce mobility (Salin, 1992). Besides a quest to improve living standards, either financially or in search of a safe place (e.g. refugees), labor migration may occur as a way to compensate for the aging of the populations and the low birth rate. However, this implies an understanding of the determinants of emigration. The selection of migrants who emigrate is of crucial importance in the establishment of relevant labor migration policies (Arthur, 1991).

It has been argued that labor migrants keep inflation low, reduce wage rates, raise rates of economic growth, benefit employers, increase and reduce the level of qualification of the workforce, and negatively affect the position of British youth as well as generate broader fears about competition and violent crime (McDowell, Batnitzky \& Dyer, 2009). Even so, in the United Kingdom, for example, labor migration is classified by the population as one of the main social problems facing the country: a claim fueled by a largely xenophobic popular press.

Discriminatory processes have an adverse effect on individuals' identification with majority. A positive approach to all discrimination would be to conceptualize this phenomenon as a default outcome resulting from under-developed policy and/or inefficient policy implementation processes (Valtonen, 2016).

Then, the executive power, which is responsible for planning public policies, needs to focus on planning migration policies that maximize the wellbeing of migrants (Hanson, 2009).

They need to know, among other values, the elasticities of wages, prices, taxes, and government transfers relative to the national workforce, and how these parameters vary across countries.
With reference to government issues, specifically about the political affairs of their country and city of residence, migrants from different national origins display different levels of political participation and interest. This is partly due to the very characteristics of ethnic minorities at the collective level, such as in the socio-demographic composition and size of the group, its migration history, its socio-economic status and its political culture (Morales \& Giugni, 2016).

A heightened role in policy-making would create stronger channels for influencing national immigration activity and growth. Immigration should be understood as a resource opportunity for receiving societies to enable them to sustain service sectors and to renew and invigorate other labor market sectors (Valtonen, 2016).

Although many migrants have professional qualifications, they are extremely poorly paid and live in precarious forms of work (McDowell, Batnitzky \& Dyer, 2009). Discrimination and noncommodification of immigrants' expertise serve to disqualify significant numbers of capable and competent persons whose contribution is needed in a critical way in their communities and in society (Valtonen, 2016). Therefore, as one may note analyzing these papers, low levels of representation of immigrants at higher levels of responsibility in organizations and in the professions are evident, even in societies with long experience of settlement and in those which otherwise have achieved advanced equality, as gender one.

Thus, empirical attention to the precarious work and migration movements is able to correct an omission along the discussions on migration to work and work-life balance (Dyer, McDowell \& Batnitzky, 2011). It also offers the opportunity for reflection on the work systems adopted today that underpins many contemporary policies and identifies their assumptions and blind spots.

\section{METHODOLOGY}

This research has a qualitative character because it is concerned with non-quantifiable aspects of reality, seeking to describe, decode, translate and deal with the meaning of a certain phenomenon (Silveira \& Córdova, 2009; Cooper et al., 2006). The methodology used was a systematic review of the international literature on precarious work and migration. The systematic review, according to Galvão, Sawada and Trevizan (2004), provides an 
organized synthesis of the information available on a specific problem through the scientific method.
Figure 01 below represents the flowchart of the procedures adopted for the production of this article.

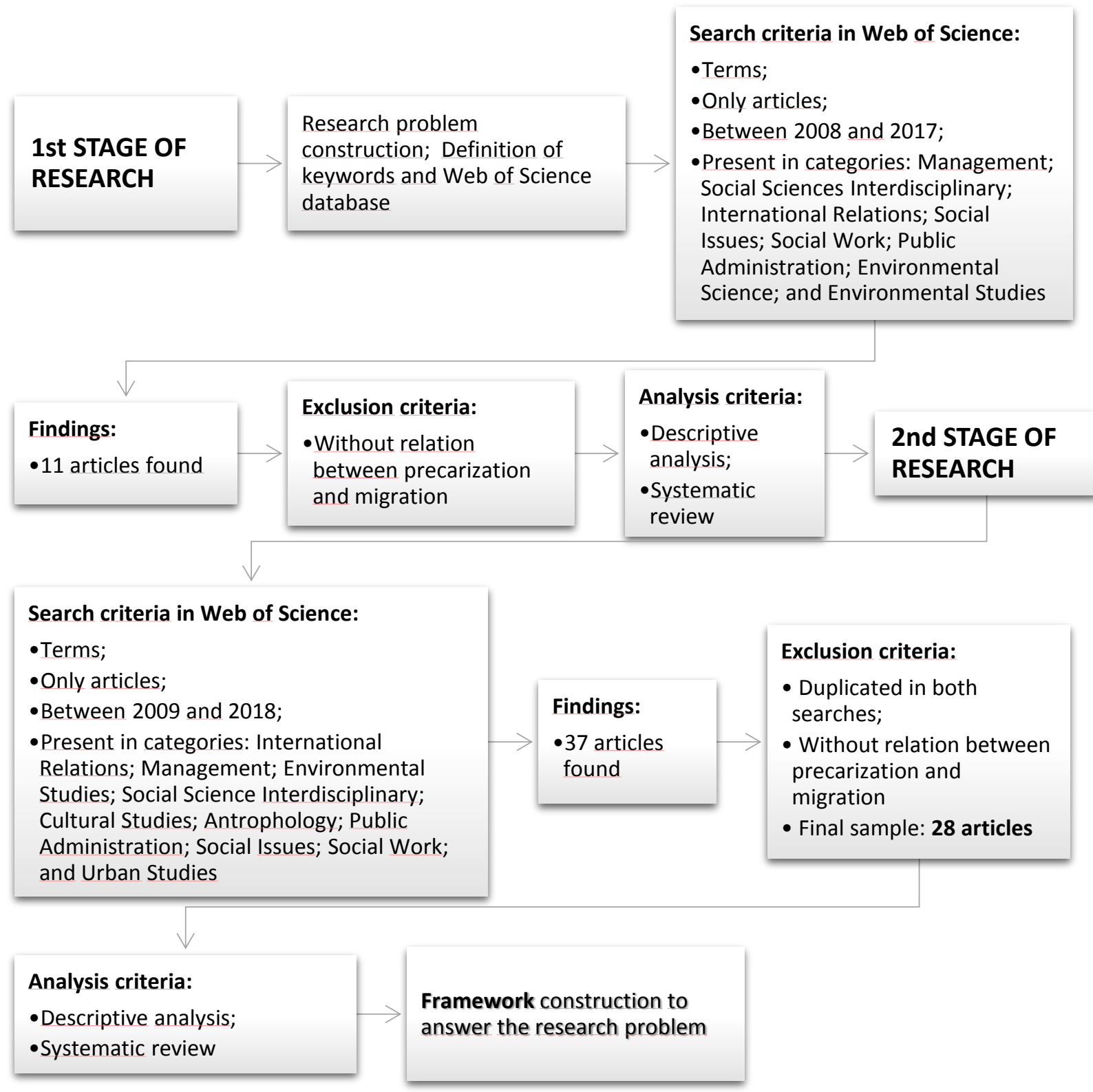

Figure 01: Flowchart of article production processes.

Source: Prepared by the authors (2019)

The source researched for the collection of articles on precarious work and migration occurred through Web of Science database. This database was selected as it was considered one of the most important bibliographic databases with a focus on business and management research (Bakker, 2010; Deng, 2012). The research period was from 2008 to 2019, since the article seeks to show the state of the art of the discussion about the two concepts.
As the figure 01 shows, in the first stage of research in Web of Science database articles were searched using the terms "precarious work" and "migration" for topic search. As exclusion criteria, the search was only used for articles from 2008 to 2017 in the following subareas: Management; Social Sciences Interdisciplinary; International Relations; Social Issues; Social Work; Public Administration, Environmental Science, Environmental Studies, since, 
amid the subcategories made available by the Web of Science database, they were more aligned with the theme. In these criteria, the research resulted in 11 articles found and after reading one of them was excluded from the research because it did not present a clear relation between the two terms (precarious work and migration) analyzed.

Aiming at a greater understanding of the issue involving precarization and migration, the second stage of research was performed with a new search inside Web Of Science database.

The new search was composed by the terms "migrate *", "precarious*", "labor" and "work*". The use of * was due to the database completing the search terms with words related to the theme (e.g. for "migrate*" the database complemented the search with the words "migrant, migration, migrations and migrate"). With reference to the term "precarious *", there is the complement of the search with "precariousness" and "precarious work". Regarding the term "work*", the database may have adding the word "worker". After defining the search terms, the publication date of papers indexed in the Web of Science was selected from 2009 to 2018. The change in the publication date in relation to the first search is justified by the fact that the present study started in 2018 and the second part of the research was carried out in 2019 - so it was possible to add one year in relation to the first stage of the research. In addition, the search criterion was adopted only for scientific articles in the categories: International Relations; Environmental Studies; Social Sciences Interdisciplinary; Cultural Studies; Anthropology; Public Administration; Social Issues; Management; Social Work; and Urban Studies, such categories are made available by the Web of Science database. It is noteworthy that the choice for these categories was by cause of the complexity and interdisciplinary that this study addresses.

From these two stages, the first search resulted in 11 papers found, and in the second search 37 papers were found totalising 48 papers. However, after reading the abstract of each article, 7 papers were excluded because they were duplicated in the both searches and 13 papers excluded from the research because they did not present a clear relation between the issue of precarious and migration.

After following the established criteria and performing the exclusions, 28 papers were chosen as data analysis corpus of the present study. In the systematic review, an adaptation of the Sarturi, Seravalli and Boaventura (2015) methodology was used, where the following information was collected: year of publications, the title of articles, authors and periodicals in which they were published. Table 1 presents the articles selected by the systematic review:

Table 01: Selected Articles by Systematic Review.

\begin{tabular}{|c|c|c|c|}
\hline Year & Title & Authors & Journal \\
\hline 2011 & $\begin{array}{l}\text { Caught in the Work-Citizenship Matrix: the Lasting Effects of } \\
\text { Precarious Legal Status on Work for Toronto Immigrants }\end{array}$ & Goldring and Landolt & Globalizations \\
\hline 2011 & $\begin{array}{c}\text { Toward a new countermovement: a framework for interpreting } \\
\text { the contradictory interventions of migrant civil society } \\
\text { organizations in urban labor markets }\end{array}$ & Martin & $\begin{array}{l}\text { Environment and } \\
\text { Planning a: Economy } \\
\text { and Space }\end{array}$ \\
\hline 2012 & $\begin{array}{l}\text { Mobility among Latin American migrants: The case of } \\
\text { Bolivians in São Paulo and Brazilians in London }\end{array}$ & Lima and Martins Jr & Employee Relations \\
\hline 2012 & $\begin{array}{l}\text { Negotiated Positions: Immigrant Women's Views and } \\
\text { Experiences of Employment in Canada }\end{array}$ & $\begin{array}{l}\text { Dlamini, Anucha and } \\
\text { Wolfe }\end{array}$ & Affilia \\
\hline 2013 & Social margins and precarious work in Vietnam & Arnold & $\begin{array}{l}\text { American Behavioral } \\
\text { Scientist }\end{array}$ \\
\hline 2013 & $\begin{array}{l}\text { Organising migrants as workers or as migrant workers? } \\
\text { Intersectionality, trade unions and precarious work }\end{array}$ & $\begin{array}{l}\text { Alberti, Holgate and } \\
\text { Tapia }\end{array}$ & $\begin{array}{l}\text { The International } \\
\text { Journal of Human } \\
\text { Resource } \\
\text { Management }\end{array}$ \\
\hline 2013 & $\begin{array}{l}\text { Brazilian Women in the International Division of } \\
\text { Reproductive Work: Constructing Subjectivities }\end{array}$ & $\begin{array}{l}\text { Carpenedo and } \\
\text { Caetano Nardi }\end{array}$ & $\begin{array}{l}\text { Revista de Estudios } \\
\text { Sociales }\end{array}$ \\
\hline 2014 & $\begin{array}{l}\text { Gendered Morality and Development Narratives: The Case of } \\
\text { Female Labor Migration from Indonesia }\end{array}$ & Chan & Sustainability Journal \\
\hline 2014 & $\begin{array}{l}\text { Labor Migration and Trafficking among Vietnamese Migrants } \\
\text { in Asia }\end{array}$ & Bélanger & $\begin{array}{l}\text { The Annals of the } \\
\text { American Academy }\end{array}$ \\
\hline
\end{tabular}




\begin{tabular}{|c|c|c|c|}
\hline & & & $\begin{array}{l}\text { of Political and Social } \\
\text { Science }\end{array}$ \\
\hline 2015 & $\begin{array}{c}\text { Precariousness and capabilities: migrant care/domestic } \\
\text { workers in two institutional contexts }\end{array}$ & Hobson and Bede & Teorija in Praksa \\
\hline 2015 & $\begin{array}{c}\text { Deslocalización de la producción y la fuerza de trabajo: } \\
\text { Bolivia - Argentina y las tendencias mundiales en la } \\
\text { confección de indumentaria }\end{array}$ & Salgado & $\begin{array}{l}\text { Revista de Estudios } \\
\text { Transfronterizos }\end{array}$ \\
\hline 2015 & $\begin{array}{l}\text { Longing for "Normal" Post-Fordism: Cape Verdean Labor- } \\
\text { Power on a Lisbon Periphery in Crisis }\end{array}$ & Weeks & $\begin{array}{l}\text { Anthropology of } \\
\text { Work Review }\end{array}$ \\
\hline 2015 & $\begin{array}{l}\text { The legalization of Rotational 24-hour care work in Austria: } \\
\text { implications for migrant care workers }\end{array}$ & Österle and Bauer & Social Politics \\
\hline 2016 & $\begin{array}{l}\text { Inhospitable workplaces? International students and paid } \\
\text { work in food services }\end{array}$ & $\begin{array}{l}\text { Campbell, Boese and } \\
\text { Tham }\end{array}$ & $\begin{array}{l}\text { Australian Journal of } \\
\text { Social Issues }\end{array}$ \\
\hline 2016 & $\begin{array}{l}\text { Migrantes como víctimas y héroes nacionales: cuestionando } \\
\text { la migración como camino al desarrollo en Indonesia }\end{array}$ & Chan & $\begin{array}{l}\text { Revista de Estudios } \\
\text { Sociales }\end{array}$ \\
\hline 2016 & $\begin{array}{l}\text { Ambivalent Precarity: Career Trajectories and Temporalities in } \\
\text { Highly Skilled Sports Labor Migration from West Africa to } \\
\text { Northern Europe }\end{array}$ & $\begin{array}{l}\text { Agergaard and } \\
\text { Ungruhe }\end{array}$ & $\begin{array}{l}\text { Anthropology of Work } \\
\text { Review }\end{array}$ \\
\hline 2016 & $\begin{array}{l}\text { The Precarious Position of Latino Immigrants in the United } \\
\text { States: A Comparative Analysis of Ethnosurvey Data }\end{array}$ & $\begin{array}{l}\text { Massey, Durand and } \\
\text { Pren }\end{array}$ & $\begin{array}{l}\text { The Annals of the } \\
\text { American Academy } \\
\text { of Political and Social } \\
\text { Science }\end{array}$ \\
\hline 2016 & $\begin{array}{l}\text { "Finding their way": the negotiation of the city by low-skilled } \\
\text { service sector migrant workers in Dublin }\end{array}$ & McPhee & Urban Geography \\
\hline 2016 & $\begin{array}{l}\text { Management of irregular migration: Syrians in Turkey as } \\
\text { paradigm shifters for forced migration studies }\end{array}$ & Canefe & $\begin{array}{l}\text { New Perspectives on } \\
\text { Turkey }\end{array}$ \\
\hline 2016 & $\begin{array}{l}\text { Syrian refugees in seasonal agricultural work: a case of } \\
\text { adverse incorporation in Turkey }\end{array}$ & Kavak & $\begin{array}{l}\text { New Perspectives on } \\
\text { Turkey }\end{array}$ \\
\hline 2016 & $\begin{array}{l}\text { The Production of Difference and Maintenance of Inequality: } \\
\text { The Place of Young Goan Men in a Post-Crisis UK Labor } \\
\text { Market }\end{array}$ & $\begin{array}{l}\text { Mcdowell, Rootham } \\
\text { and Hardgrove }\end{array}$ & $\begin{array}{l}\text { Gender, Work \& } \\
\text { Organization }\end{array}$ \\
\hline 2016 & $\begin{array}{l}\text { The Neoliberal Governance of Global Labor Mobility: Migrant } \\
\text { Workers and the New Constitutional Moments of Primitive } \\
\text { Accumulation }\end{array}$ & Onuki & $\begin{array}{l}\text { Alternatives: Global, } \\
\text { Local, Political }\end{array}$ \\
\hline 2017 & $\begin{array}{l}\text { Condiciones laborales de migrantes bolivianas que realizan } \\
\text { trabajo de cuidado en Iquique }\end{array}$ & $\begin{array}{l}\text { Gómez, Agüero and } \\
\text { Fornes }\end{array}$ & $\begin{array}{l}\text { Revista de Estudios } \\
\text { Transfronterizos }\end{array}$ \\
\hline 2017 & $\begin{array}{l}\text { On the edge: changing geographies of the global city } \\
\text { precariat in London and Hong Kong }\end{array}$ & $\begin{array}{l}\text { Jordan, DeVerteuil, } \\
\text { Kandt, Manley and } \\
\text { Wu }\end{array}$ & Urban Geography \\
\hline 2017 & $\begin{array}{c}\text { Global city and precarious work of migrants in China: a } \\
\text { survey of seven cities }\end{array}$ & Sun and Chen & Urban Geography \\
\hline 2017 & $\begin{array}{l}\text { Organizing Latin American workers in Japan The case of the } \\
\text { community union MIE as an alternative space of regulation }\end{array}$ & $\begin{array}{l}\text { Stewart, Danford and } \\
\text { Urano }\end{array}$ & Employee Relations \\
\hline 2018 & $\begin{array}{l}\text { Hanging Out Together, Surviving on Your Own: The } \\
\text { Precarious Communities of Day Laborers }\end{array}$ & Fernández & $\begin{array}{l}\text { Journal of } \\
\text { Contemporary } \\
\text { Ethnography }\end{array}$ \\
\hline 2018 & $\begin{array}{l}\text { Forced transnationalism and temporary labor migration: } \\
\text { implications for understanding migrant rights }\end{array}$ & Piper and Withers & Identities \\
\hline
\end{tabular}

Source: Prepared by the authors (2019)

Sequentially, tables and explanatory texts about the articles examined were presented in the next section. The analysis presented, at first, an overview of the articles investigated, in terms of evolution and geographic regions where they were elaborated, and later falls on the more detailed analysis of the specificities of the work in terms of objectives, relations, methodologies and main contributions.

\section{FINDINGS AND DISCUSSION}

Although the literature on precarious work and the literature on migration are two well-established 
fields, the relation between the two concepts has still been little explored by the researchers evidenced by the relatively few researches found in the databases.
Figure 02 shows the development over time of the twenty-eight studies selected for analysis.

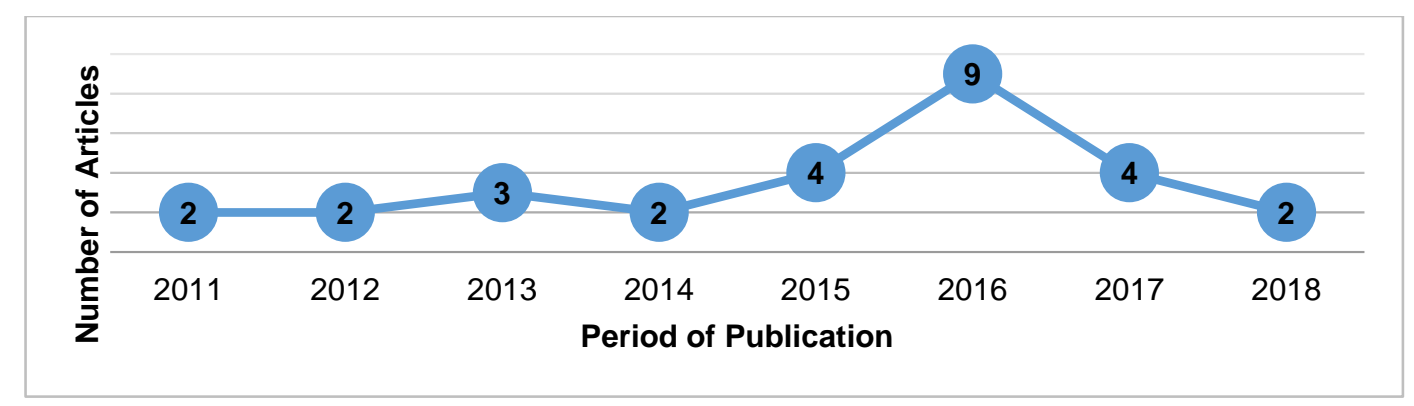

Figure 02: Development of the research theme. Source: Prepared by the authors (2019)

Figure 02 shows that no studies were found in the period 2008 - 2010, according to the methodological criteria adopted in this research. It was observed that from 2011 until the 2018 there was at least one survey per year, and the height of publication was in 2016 with 9 articles published in journals.

The keywords of the papers may be adopted as search criteria in databases. In this sense, an inspection of the keywords presented in the analyzed papers was done. As a result, amidst the 28 articles analyzed, 39\% presented five keywords, $18 \%$ presented six keywords, and $14 \%$ with four keywords. Curiously, $11 \%$ of the papers did not have keywords and the remaining percentage of articles presented between two and one keyword. Keywords that appear most frequently are: Migration; Precarious work; Migrant workers; Migrant; Precarity; Gender; Immigration; Labor and Development. These keywords are exposed as word cloud in figure 03. It may help to foster the debate of the theme betwixt researchers.

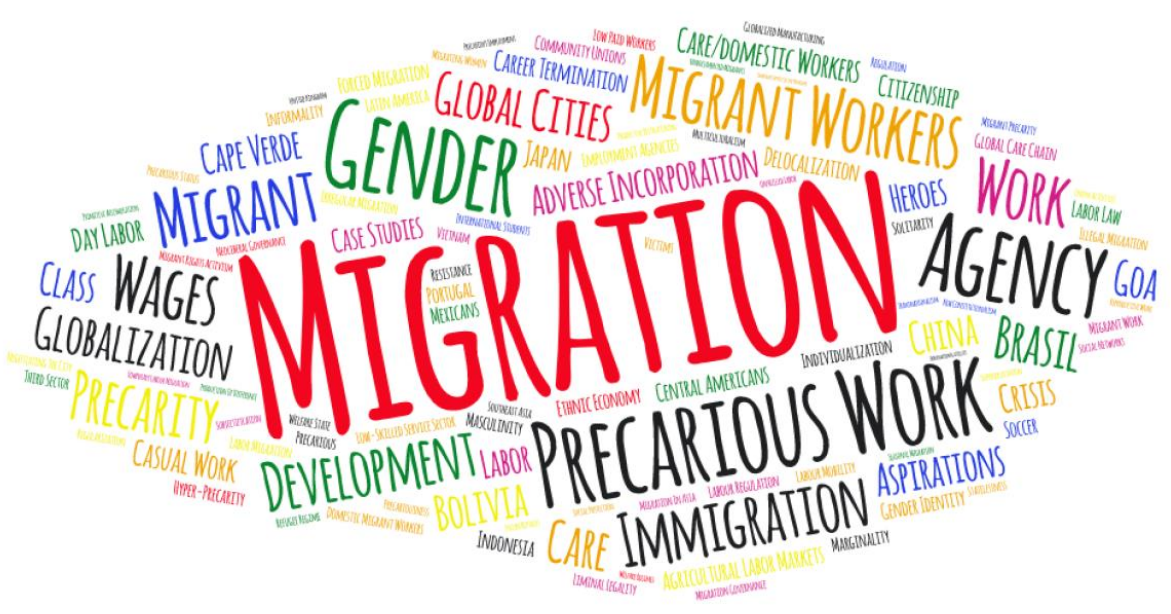

Figure 03: Keyword cloud present in the analyzed articles.

Source: Prepared by the authors (2019)

In relation to the general methodological aspects, 93\% of the articles analyzed are empirical and the other $7 \%$ are theoretical. Regarding the quali or quanti nature, $68 \%$ are analyzed through qualitative approaches and $11 \%$ are the articles that use quantitative methods in the analysis. Another 21\% adopted mixed methodologies to seek to characterize contextual aspects of precariousness.
Due to the qualitative nature of the research, most studies analyzed (43\%) collected data through structured and semi-structured interviews with migrant workers, civil servants, public, private and NGO managers; followed by the use of secondary data (29\%), such as government news and official speeches and media news, websites, documents, reports and general data from organizations and NGOs; and survey (3\%). It should be noted that some 
quanti studies used more than one data collection method. Then, in studies that adopted a mixed methodology, 22\% used surveys and interviews as a data source and another $3 \%$ used secondary data and interviews.

Figure 04 demonstrates this relation between the nature of the research and the method of data collection. There is a discrepancy between the number of papers analyzed (28 documents) and the sum shown in figure 04 (35 documents). This discrepancy occurs because the 6 papers that used mixed methods (i.g. survey and interview were counted twice). One qualitative paper was also counted twice since it had as its source of data interviews and secondary data.

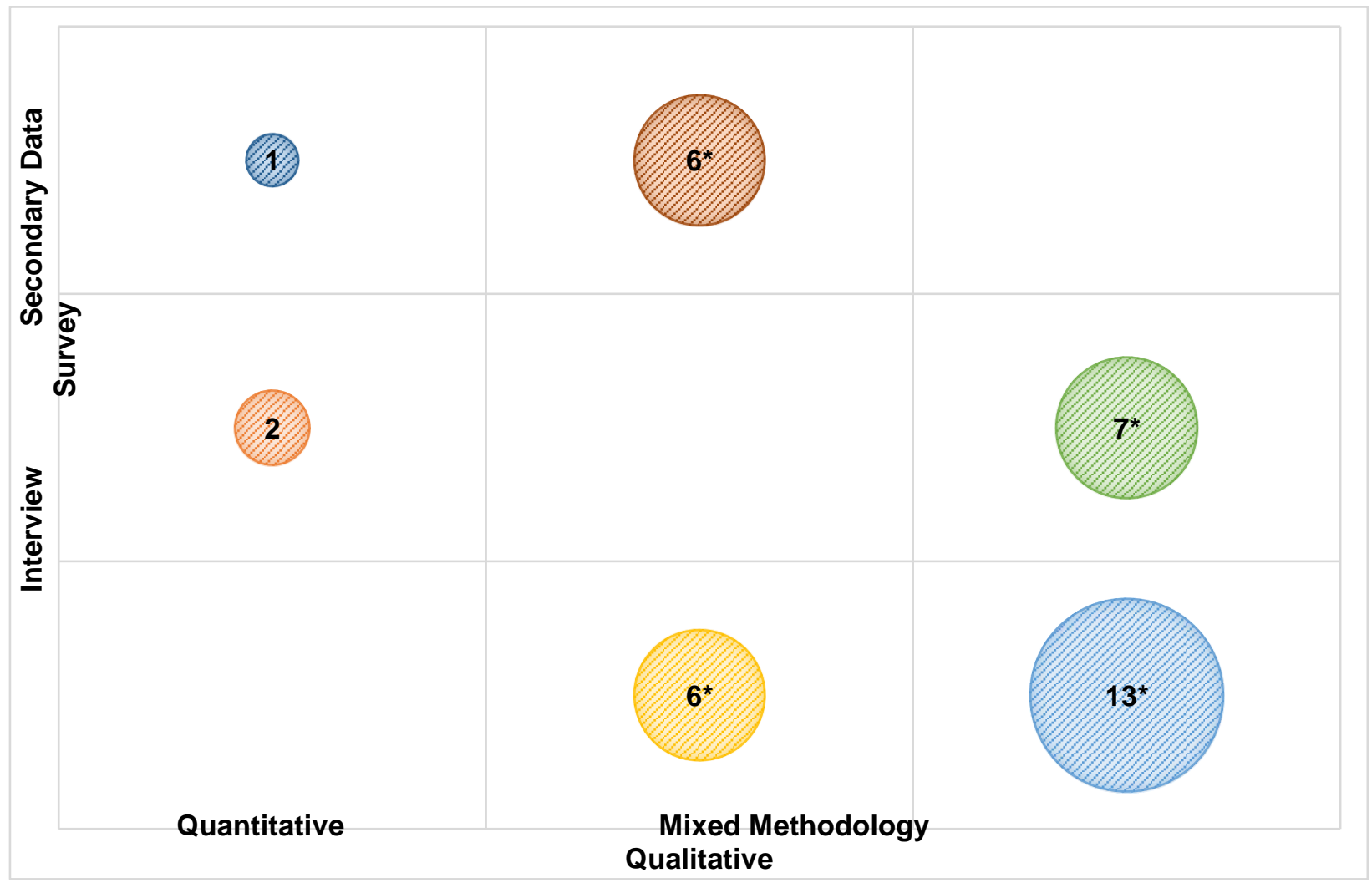

Figure 04: Nature of research.

Source: Prepared by the authors (2019)

We collected 28 articles present in 20 journals. The Journals that stand out with the most publications on precarization and migration are: Urban Geography with 3 published articles; and The Annals of the American Academy of Political and Social Science, "Revista de Estudios
Transfronterizos", "Revista de Estudios Sociales", New Perspective on Turkey, Employee Relations and Anthropology of Word Review with two articles each. The other journals published only one article each on the topic - as we can see in figure 05. 


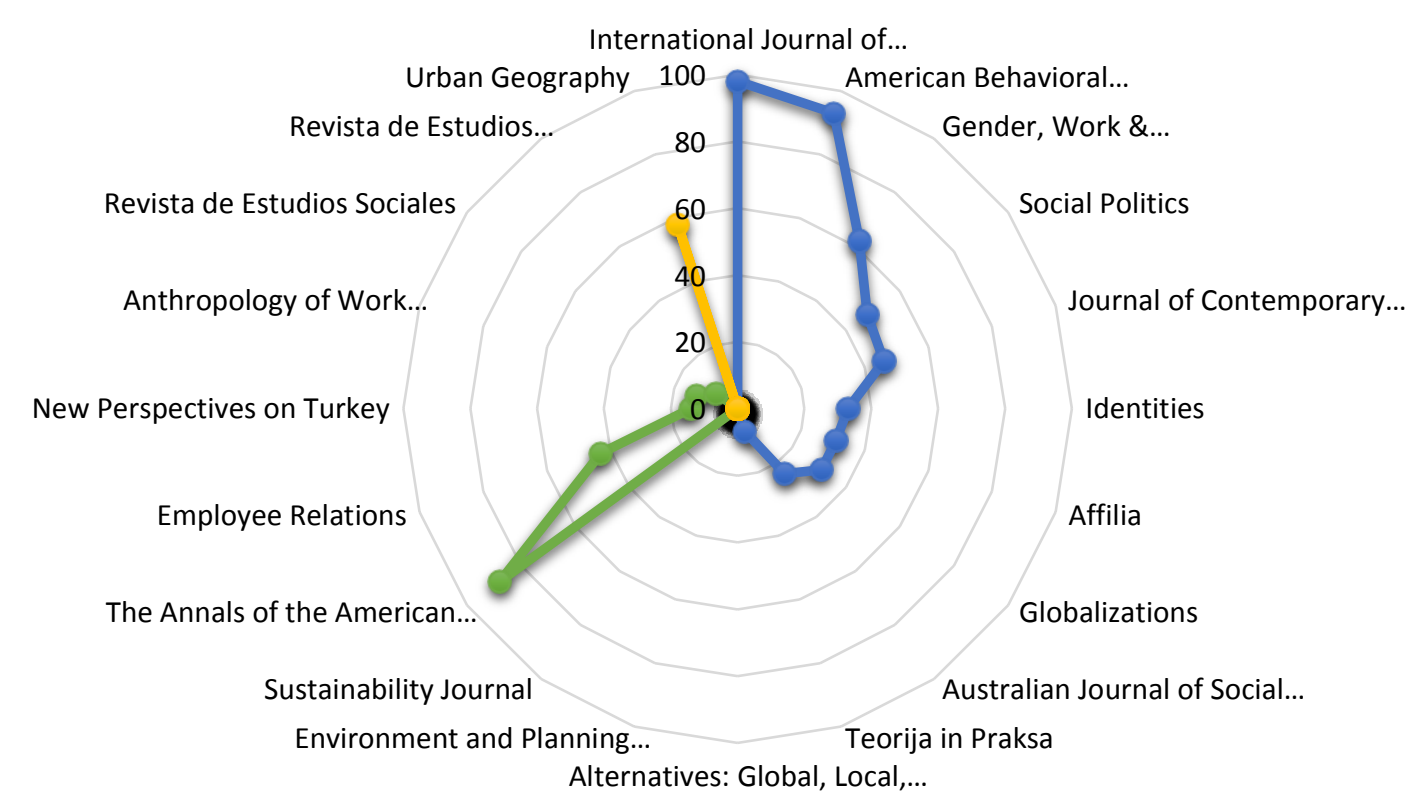

Figure 05: Periodics with articles about the theme.

Source: Prepared by the authors (2019)

Also in figure 05 is exposed the relation between the number of papers published and the impact factor of the journals according to the Scimago (SJR) ranking. To ensure the authenticity and accuracy of its assessments, the SJR indicator uses citation analysis algorithms in a range of journals from different countries and in several languages (Falagas et al., 2008).

A journal with a high impact factor for the academic community exposes relevant works that consequently generate debate amid authors through citations. Thus, among the 20 journals analyzed in this paper it is possible to observe in figure 05 that with 3 publications on the subject there is only 1 periodical by yellow colour; with 2 publications there are 6 journals represented by the colour green; and 7 journals represented by the colour blue with 1 publication each.

Furthermore, a more detailed analysis of the specific characteristics of each article is presented in Appendix. There, each work was presented in relation to its research objective, a relation between precarization of work and migration, followed by the methodological procedures adopted in each research, and finally, the main contributions of the researches.

The results show that there may be a relation between precarious work and migration since labor migration tends to occur when there are no favorable working conditions - while working conditions are precarious in the country of origin (Chang, 2009). However, the precarious situation in the migrant's life does not start exclusively at the same time that he arrives at the destination country. Many people leave their countries, often in developing stages, motivated by the promise of higher financial returns abroad (Nekby, 2006) and the promise of better living conditions in developed countries whereas compared to their home country. Nevertheless, they may get surprised upon they realize that the expectation created does not match reality and that is the precarization (Mcdowell, Rootham \& Hardgrove, 2016).

It would not be wrong to say that the precarization of migrant workers may be an onus generated by capitalism. Due to the evidence found in the analyzed papers, we point out that the international migration of labor supported by the capitalism (Arnold \& Bongiovi, 2013) and new neoliberal guidelines (Fernández, 2018) may be facts that generate the precarization of the work and the worker (Lima \& Martins Jr, 2012). They force producers from different countries to become more competitive to survive (Kalleberg, 2009).

As a result of the new economic dynamics imposed by capitalism and neoliberal policies, global 
cities (Jordan et al., 2017) are marked by precarization. Everyday situations, such as migrants living in outlying areas, far from the city center or workplace, with limited access to public services and/or needing to share housing with more people to reduce spending (McPhee, 2016), expose migrant workers to humiliation, shame and precarization. In sum, this economic system is increasingly present in the lives of many migrants affecting their well-being and are a crucial factor in the precarization and position in the world labor market (Massey, Durand \& Pren, 2016).

In addition, according to these new work guidelines imposed by capitalism, the flexibilization of work may be the cause of the loss of social rights and worker protection - the lack of legal rights to protect migrant workers from precarization (Kalleberg \& Hewison, 2013). The growth of the informal economy and the lack of institutionalized worker protection may explain the precarization imposed by the market (Chang, 2009). Arnold (2012) reiterates that there is a lack of institutional protection for migrant workers because, as seen in the work of Campbell et al. (2016), workers in informal work situations (i.e. work without legal guarantees) are more subject to illegal hiring practices and working conditions.

The future migrant, still in his home country, comprehending that his legal and economic rights are threatened because of the flexibility in labor relations imposed by capitalism (Antunes \& Praun, 2015), decides to migrate to another country. In this sense, Piper \& Withers (2018) indicate that there are organizations that recruit people to work abroad. In theory, these companies should assist in the entire worker migration process, but in practice they offer temporary employment contracts and even jobs that do not offer migrant workers rights and access to public services. Based on this fact, we believe that they may also be responsible for the precarious situation of the migrant worker.

Moreover, the migrant worker, within these new guidelines of work imposed by capitalism, is essential to various sectors of the economy of developed countries because they are considered a manual workforce (Weeks, 2016). Migrant workers are generally not opposed to hard work such as cleaning and construction, setting aside their real qualifications and submitting to jobs that require low or no qualifications, risk of occupational accidents, low wages and risk of apprehension and deportation in the country in the case of illegal migrants (Martin, 2011).

Precarization of migrant workers, then, may be ambivalent (Agergaard \& Ungruhe, 2016). If, on the one circumstances, people migrate to another country looking for better living conditions and end up living in precarious conditions, on other hand, these same people in some cases get access to benefits and social protection that they did not have in their home countries (Österle \& Bauer, 2015).

Thusly, the migrant worker allows himself to be in a precarious situation, with no prospect of a professional future or social welfare simply for the sake of work, for feeling that being there, in that position he is self-fulfilling. An example of this ambivalence is football players born in African countries who migrate to European countries and undergo temporary work in precarious situations because they are doing what they like: playing football (Agergaard \& Ungruhe, 2016).

Furthermore, the ambivalence about the issue of migrant workers may also be portrayed by gender. Although, on the one hand, the discussion about gender equality is current, on the other hand, we still live in a patriarchal society (Dlamini, Anucha \& Wolfe, 2012). The precarization of female migrant workers may present itself as actions coming from the public power that legitimize precarization. In the context of Indonesia, for example, Chan (2014) pointed out that the gender of the worker guides whether he deserves the attention of the rulers and the media regarding the precarious situation.

Also in these point, more recently, Chan (2016) showed that the exploration of migrant workers is often legitimized by the state and public policy makers. This legitimation of the precarization experienced by female workers tends to occur through the storytelling of Indonesian authorities who emphasize that there is tolerable violence and precarious practices linked to migrant workers. Such evidence may lead us to the understanding that since a nation's public power does not protect workers, whether they are migrants or not, the population and the general market will grasp the message that precarization is a legitimate practice.

So, the executive branch responsible for public policy planning should focus on planning migratory policies that maximize migrant welfare (Hanson, 2009) rather than helping to increase precariousness. 
In the meantime, with the legitimation of the precarization of migrant workers by the public power and the lack of public policies that protect them, Kavak (2016) presents the concept of hyperprecarization as the inability of workers to negotiate their needs to face sustained pressures and shortterm survival. Because of the easing of labor relations in the name of economic liberalism, the migrant worker, in a situation of hyper-precarization, is vulnerable to any offer that the labor market offers in the name of survival. As a result, the market may force migrant workers into situations of insecurity and informality in the workplace.

The evidence, therefore, indicates that the precarization of migrant workers is directly associated with the legal and contractual insecurity to which these workers are prone. It is in this consonant that Bélanger (2014) points out that the precarization of migrants may be a continuum that involves forced labor, exploitation, abuse and precariousness from the moment of recruitment.

Other point is that the precarization that occurs in the migratory movements may be a historical inheritance. Onuki (2016) shows that there is a tendency of migration from the southern hemisphere to the northern hemisphere as many emerging countries in the southern part of the globe were colonized by countries considered developed from the northern hemisphere. As result, meanwhile migrating to these developed countries, these migrants suffer prejudice simply because of their nationality, accent, skin color, age and even physical appearance (Mcdowell, Rootham \& Hardgrove, 2016). These factors create unsatisfactory conditions and help to increase the precarization of migrant workers.

Education may be a factor for precarious work as well. Sun and Chen (2017) point out that the level of education affects the intensity of precarization, in other words, migrant workers with access to information and knowledge are less likely to live in precarious situations. Nonetheless, it is also evidenced by McDowell, Batnitzky and Dyer (2009) that even with a good qualification, the risk of precarizaton still exists.

The fact that they are migrants may help them to be exposed to the new dynamics of labor relations imposed by capitalism system. In such a way the migrant worker may have a job with minimum or neither rights, with low wages and living poorly both in the workplace and in personal and daily life.

Proposing a theoretical model of the two phenomenons - precarious work and migration based on articles analyzed, we highlight that people migrate between countries for economic, social or political factors. Common of these three reasons is the desire to have a better life conditions. Even in some cases these migrants get access to benefits, they probably will suffer some kind of precariousness - whether in unhealthy services, without legal protection or living in unsuitable housing. This is the ambivalent nature of the precarious work - and its consequences. In theory, what should help to diminish the precarious work of migrants are imposing regulatory norms, which in fact may be helping to increase it, and as a result hyperprecarization occurs. Public power should elaborate public policies to protect migrant workers and do not promote the legitimation of their precarization. The lack of these policies may turn the public power into an agent that fosters precarization. Then, there is no specific character for the migrant: they can be of all genders, nationalities, educational levels, ages or professions. That is why it is important to consider all possible characters when studying this theme.

\section{FINAL CONSIDERATIONS}

This study aimed to show the relation between precarious work and migration through a systematic review of the indexed literature in the international database Web of Science from 2008 to 2018, which analyzed 28 articles related to the terms precarious work and migration. Assessing the relation between the precariousness of work and labor migration in the selected articles, we can see that there is a relation between the terms and contribute to the field by bringing a standardized and systematic scientific information that may assist in the development of the field.

Due to the transformations of the industry (Salgado, 2015), which lead to the lack of rights guarantees (Arnold, 2012), the work is precarious. At the same time it may be the cause of the migratory movements of workers that, in turn, find themselves immersed in a recurrent movement: the recidivism of the precarization.

In the meantime, studies involving migration processes and especially labor may provide an understanding not only of territorial mobility but also 
of market aspects such as the economic, behavioral and subjective factors of the decision maker. On the worker side, migration studies may unveil perceptions about the role of labor movements and about the manifestations of the relation between population, resources and economic development.

The analyzed articles clarify the need to expand the issue in evidence because if we investigate the terms precarious work and migration in a different way, the results will be numerous. However, when the search is about the relation between the terms, results are fewer, meaning that with more studies that address the relation between precarious work and migration it is possible to clarify everyday events that often go unnoticed among managers in the public and private sphere as well as in society through the lens of science.

Our discussion based on the analyzed articles could support us to offer a theoretical framework. An individual's migration may be motivated by several factors that we have to take into account. In addition, the resulting consequences of such migration, such as precarization at work, well-being, and social relations, may have deeper impacts than a mere change in the economy of the destination country.

Thus, the terms "precarious work and immigration" and "emigration", as these terms are adjuncts to the concept of migration, are indicated as topics for future research. Vulnerability is seen as an effect of pracarization of the migrant worker. Therefore, future studies that address and compare the vulnerability of migrant workers on account of their social status, whether as temporary workers, legal status, illegality, as a refugee and also issues related to gender and sexual orientation are welcome.

Researchers are encouraged to examine the phases of the precarization process from a

\section{REFERENCES}

Agergaard, S., \& Ungruhe, C. (2016). Ambivalent precarity: Career trajectories and temporalities in highly skilled sports labor migration from West Africa to Northern Europe. Anthropology of Work Review, 37(2), 67-78.

Alberti, G., Holgate, J., \& Tapia, M. (2013). Organising migrants as workers or as migrant workers? perspective that elucidates the causes and effects of the precarization of migrant workers from the moment of recruitment in the country of origin to the exercise of their activities in the new country. Still dealing with the causes, future studies can perform a historical analysis of the migratory movements that resulted in the precarization of the worker. In this regard, the following factors may be addressed: social, political, economic and cultural in the precarious situation of migrant workers.

Future studies could also explain the roles of agents present in the precarization process. That is, how - the family, the country of origin and the destination country, the religion, the company that the migrant works, the unions, and associations that assist - drive to reduce or increase the effects of precarious migrant workers.

In the meantime, we encourage researchers to address the relation between migrant workers and the host community. To clarify and demystify the relation between them through questions such as "is precarization process similar between migrants and locals?" and "are there frictions between the host community and migrants?"

Future studies that relate to the precarization of migrant workers with neoliberal strategies, new dynamics in labor relations, flexibility in labor rules, worker exploitation, temporary contracts, and corporate social responsibility may shed light on and deepen understanding of the field.

Moreover, the phenomena of precarization and migration may be evidenced in future studies through theoretical lenses such as institutionalism, networks, internationalization, and sensemaking. Adopting methodologies such as life history, ethnography, survey, interviews and mixed methods that approach the nuances and show approximation, depth and leading to a possible generalization on the subject.

Intersectionality, trade unions and precarious work. The International Journal of Human Resource Management, 24(22), 4132-4148.

Alves, G. (2007). Dimensões da reestruturação produtiva: ensaios de sociologia do trabalho. Londrina/Bauru. Praxis/Canal, 6, 298.

Antunes, R., \& Praun, L. (2015). A sociedade dos adoecimentos no trabalho. Serv. Soc. Soc., São Paulo, 123, 407-27. 
Arnold, D. (2012). Social margins and precarious work in Vietnam. American Behavioral Scientist, 57(4), 468-487.

Arnold, D., \& Bongiovi, J. R. (2013). Precarious, informalizing, and flexible work: Transforming concepts and understandings. American Behavioral Scientist, 57(3), 289-308.

Arthur, J. A. (1991). Interregional migration of labor in Ghana, West Africa: Determinants, consequences and policy intervention. The Review of Black political economy, 20(2), 89-103.

Bélanger, D. (2014). Labor migration and trafficking among Vietnamese migrants in Asia. The Annals of the American Academy of Political and Social Science, 653(1), 87-106.

Berry, D., \& Bell, M. P. (2018). Worker cooperatives: alternative governance for caring and precarious work. Equality, Diversity and Inclusion: An International Journal, 37(4), 376-391.

Betti, E. (2016). Precarious work: Norm or exception of capitalism? Historicizing a contemporary debate: A global gendered perspective. The Power of the Norm: Fragile Rules and Significant Exceptions, 35.

Bresser-Pereira, L. C. (2015). After the demise of neoliberalism but not of conservatism, a third developmentalism?.

Campbell, I., \& Price, R. (2016). Precarious work and precarious workers: Towards an improved conceptualisation. The Economic and Labor Relations Review, 27(3), 314-332.

Campbell, I., Boese, M., \& Tham, J. C. (2016). Inhospitable workplaces? International students and paid work in food services. Australian Journal of Social Issues, 51(3), 279-298.

Canefe, N. (2016). Management of irregular migration: Syrians in Turkey as paradigm shifters for forced migration studies. New Perspectives on Turkey, 54, 9-32.

Carpenedo, M., \& Caetano Nardi, H. (2013). Brazilian Women in the International Division of Reproductive Work:: Constructing Subjectivities. Revista de Estudios Sociales, (45), 96-109.

Chan, C. (2014). Gendered morality and development narratives: The case of female labor migration from Indonesia. Sustainability, 6(10), 69496972.

Chan, C. (2017). Migrantes como víctimas y héroes nacionales: cuestionando la migración como camino al desarrollo en Indonesia. Revista de Estudios Sociales, (59), 30-43.
Chang, D. O. (2009). Informalising labor in Asia's global factory. Journal of contemporary Asia, 39(2), 161179.

Cooper, D. R., Schindler, P. S., \& Sun, J. (2006). Business research methods (Vol. 9). New York: McGraw-Hill Irwin.

De Haas, H. (2010). Migration and development: A theoretical perspective 1. International migration review, 44(1), 227-264.

Dlamini, N., Anucha, U., \& Wolfe, B. (2012). Negotiated positions: Immigrant women's views and experiences of employment in Canada. Affilia, 27(4), 420-434.

Dyer, S., McDowell, L., \& Batnitzky, A. (2011). Migrant work, precarious work-life balance: What the experiences of migrant workers in the service sector in Greater London tell us about the adult worker model. Gender, Place \& Culture, 18(5), 685-700.

Falagas, M. E., Kouranos, V. D., Arencibia-Jorge, R., \& Karageorgopoulos, D. E. (2008). Comparison of SCImago journal rank indicator with journal impact factor. The FASEB journal, 22(8), 2623-2628.

Fernández, M. (2018). Hanging Out Together, Surviving on Your Own: The Precarious Communities of Day Laborers. Journal of Contemporary Ethnography, 47(6), 865-887.

Galvão, C. M., Sawada, N. O., \& Trevisan, M. A. (2009). Revisão sistemática: recurso que proporciona a incorporação das evidências na prática da enfermagem. Rev Lat Am Enferm. 2004; 12 (3): 549-56. Rev Esc Enferm USP, 43(2), 465-71.

Goldring, L., \& Landolt, P. (2011). Caught in the work-citizenship matrix: The lasting effects of precarious legal status on work for Toronto immigrants. Globalizations, 8(3), 325-341.

Golgher, A. B. (2004). Fundamentos da migração. Belo Horizonte: UFMG/Cedeplar.

Gómez, Sandra Leiva., Agüero, Miguel Ángel Mansilla., \& Fornes, Andrea Comelin. (2017). Condiciones laborales de migrantes bolivianas que realizan trabajo de cuidado en Iquique. Si Somos Americanos, 17(1), 11-37.

Hanson, G. H. (2009). The economic consequences of the international migration of labor. Annu. Rev. Econ., 1(1), 179-208.

Hirst, P., \& Thompson, G. (1998). A Globalização em questão a economia internacional e as possibilidades de governabilidade. Petrópolis: Vozes. 
Hobson, B., \& Bede, L. (2015). Precariousness and capabilities: Migrant care/domestic workers in two institutional contexts. Teorija in Praksa, 52(3), 327-349.

Jordan, L. P., DeVerteuil, G., Kandt, J., Manley, D., \& $\mathrm{Wu}, \mathrm{Q}$. (2017). On the edge: changing geographies of the global city precariat in London and Hong Kong. Urban geography, 38(10), 1459-1478.

Kalleberg, A. L. (2009). Precarious work, insecure workers: Employment relations in transition. American sociological review, 74(1), 1-22.

Kalleberg, A. L. (2012). Job quality and precarious work: Clarifications, controversies, and challenges. Work and Occupations, 39(4), 427-448.

Kalleberg, A. L., \& Hewison, K. (2013). Precarious work and the challenge for Asia. American Behavioral Scientist, 57(3), 271-288.

Kavak, S. (2016). Syrian refugees in seasonal agricultural work: a case of adverse incorporation in Turkey. New Perspectives on Turkey, 54, 33-53.

Kim, I. H., Khang, Y. H., Muntaner, C., Chun, H., \& Cho, S. I. (2008). Gender, precarious work, and chronic diseases in South Korea. American journal of industrial medicine, 51(10), 748-757.

La Boétie, É. D. (2015). Discours de la servitude volontaire. Flammarion.

Lee, E. S. (1966). A theory of migration. Demography, 3(1), 47-57.

Lima, J., \& Martins Jr, A. (2012). Mobility among Latin American migrants: the case of Bolivians in São Paulo and Brazilians in London. Employee Relations, 34(6), 594-612.

Lucassen, L. (2016). Working together: new directions in global labor history. Journal of Global History, 11(1), 6687.

Martin, N. (2011). Toward a new countermovement: a framework for interpreting the contradictory interventions of migrant civil society organizations in urban labor markets. Environment and Planning a, 43(12), 2934-2952.

Massey, D. S., Arango, J., Hugo, G., Kouaouci, A., Pellegrino, A., \& Taylor, J. E. (1993). Theories of international migration: A review and appraisal. Population and development review, 19(3), 431-466.

Massey, D. S., Durand, J., \& Pren, K. A. (2016). The precarious position of Latino immigrants in the United States: A comparative analysis of ethnosurvey data. The Annals of the American Academy of Political and Social Science, 666(1), 91-109.
McDowell, L., Batnitzky, A., \& Dyer, S. (2009). Precarious work and economic migration: emerging immigrant divisions of labor in Greater London's service sector. International Journal of Urban and Regional Research, 33(1), 3-25.

McDowell, L., Rootham, E., \& Hardgrove, A. (2016). The production of difference and maintenance of inequality: The place of young Goan men in a post-crisis UK labor market. Gender, Work \& Organization, 23(2), 108-124.

McPhee, S. R. (2016). "Finding their way": the negotiation of the city by low-skilled service sector migrant workers in Dublin. Urban Geography, 37(3), 396-415.

Morales, L., \& Giugni, M. (Eds.). (2016). Social capital, political participation and migration in Europe: making multicultural democracy work?. Springer.

Neilson, B., \& Rossiter, N. (2008). Precarity as a political concept, or, Fordism as exception. Theory, Culture \& Society, 25(7-8), 51-72.

Nekby, L. (2006). The emigration of immigrants, return vs onward migration: evidence from Sweden. Journal of Population Economics, 19(2), 197226.

Onuki, H. (2016). The neoliberal governance of global labor mobility: migrant workers and the new constitutional moments of primitive accumulation. Alternatives, 41(1), 3-28.

Österle, A., \& Bauer, G. (2015). The legalization of rotational 24-hour care work in Austria: Implications for migrant care workers. Social Politics, 23(2), 192-213.

Paltrinieri, L. (2017). Managing Subjectivity: Neoliberalism, Human Capital and Empowerment. Fudan Journal of the Humanities and Social Sciences, 10(4), 459-471.

Piper, N., \& Withers, M. (2018). Forced transnationalism and temporary labor migration: implications for understanding migrant rights. Identities, 25(5), 558-575.

Sabot, R. (2019). Migration and the labor market in developing countries. Routledge.

Salgado, P. D. (2015). Deslocalización de la producción y la fuerza de trabajo: Bolivia-Argentina y las tendencias mundiales en la confección de indumentaria. Si Somos Americanos, 15(1), 169-198.

Salim, C. A. (2016). Migração: o fato e a controvérsia teórica. Anais, 119-144. 
Sarturi, G., Seravalli, C., \& Boaventura, J. M. G. (2015). Afinal, o que é distribuir valor para os stakeholders? Uma análise bibliográfica sobre o tema. Revista de Administração da UFSM, 8, 92-113.

Silveira, D. T., \& Córdova, F. P. (2009). Unidade 2-A pesquisa científica. Métodos de pesquisa, 1.

Stewart, P., Danford, A., \& Urano, E. (2017). Organizing Latin American workers in Japan: The case of the community union MIE as an alternative space of regulation. Employee Relations, 39(3), 365-377.

Strauss, K. (2018). Labor geography 1: Towards a geography of precarity?.Progress in Human Geography, 42(4), 622-630.

Sun, Z., \& Chen, J. (2017). Global city and precarious work of migrants in China: A survey of seven cities. Urban Geography, 38(10), 1479-1496.
Valtonen, K. (2016). Social work and migration: Immigrant and refugee settlement and integration. Routledge.

Vera, Francisco., \& Alves, E. de A. (1985). Urbanização: desafio à produtividade agrícola. Área de Informação da Sede-Artigo em periódico indexado (ALICE).

Weeks, S. (2015). Longing for "Normal" Post-Fordism: $\mathrm{C}$ ape $\mathrm{V}$ erdean Labor-Power on a Lisbon Periphery in Crisis. Anthropology of Work Review, 36(1), 13-25.

Wilson, S., \& Ebert, N. (2013). Precarious work: Economic, sociological and political perspectives.

Young, Marisa. C. (2010). Gender differences in precarious work settings. relations industrielles/industrial relations, 65(1), 74-97.

\section{About Authors}

Guilherme Primo Matias - Universidade de São Paulo - USP, São Paulo, SP, (Brasil). E-mail: guiimatias@gmail.com Orcid id: https://orcid.org/0000-0002-2385-1188

Gabrielle Ribeiro Rodrigues da Silva - Universidade Federal do Paraná - UFPR, Curitiba, PR, (Brasil). E-mail: gabii.ribeiiro@hotmail.com Orcid id: https://orcid.org/0000-0001-6638-130X

Fabio Emanuel Farago - Universidade de São Paulo - USP, São Paulo, SP, (Brasil_. E-mail: fabio.farago@hotmail.com Orcid id: https://orcid.org/0000-0003-0869-7220 


\title{
PRECARIZAÇÃO DO TRABALHO E MIGRAÇÃO: UMA REVISÃO DA LITERATURA INTERNACIONAL
}

\author{
Guilherme Primo Matias, Gabrielle Ribeiro Rodrigues da Silva, Fabio Emanuel Farago \\ Universidade Federal do Paraná - UFPR, Paraná, (Brasil) \\ Universidade de São Paulo - USP, São Paulo, (Brasil)
}

\section{DETALHES DO ARTIGO}

\section{Histórico do Artigo:}

Recebido: 15 de fevereiro de 2019

Aceito: 01 de novembro de 2019

Disponível online: 01 de jan. de 2020

review"

Sistema de revisão "Double blind review"

Editor Científico

Ilan Avrichir

\author{
Palavras-Chave \\ Trabalho precário \\ Processo de migração \\ Precarização \\ Trabalhador \\ Revisão sistemática
}

\begin{abstract}
RESUMO
Objetivo: Esta pesquisa tem como objetivo destacar a relação entre precarização do trabalho e migração, com base no entendimento de que os trabalhadores migrantes são participantes no processo de desenvolvimento econômico e social dos países.

Método: A metodologia utilizada foi uma revisão sistemática da literatura internacional sobre trabalho precário e migração no período de 2008 a 2018. Principais resultados: As pessoas migram entre países por fatores econômicos, sociais ou políticos. Comum dessas três razões é o desejo de ter melhores condições de vida. Mesmo em alguns casos, esses migrantes têm acesso a benefícios, provavelmente sofrerão algum tipo de precariedade - seja em serviços insalubres, sem proteção legal ou vivendo em moradias inadequadas. Essa é a natureza ambivalente do trabalho precário - e suas consequências. Relevância/originalidade: Observa-se que grande parte da pesquisa sobre migração nos países menos desenvolvidos começou com proposições emprestadas de pesquisadores que codificaram a experiência dos países desenvolvidos. É necessário em nosso campo apresentar um exame sistemático de como a precarização e a migração são abordadas nos estudos organizacionais.

Contribuições teóricas/metodológicas: Como contribuição para o campo, neste artigo é proposto um modelo teórico que envolve os dois fenômenos e fornece ao leitor informações científicas padronizadas e sistemáticas que podem auxiliar no desenvolvimento do campo, mapeando o conhecimento existente nesse assunto.
\end{abstract}


PRECARIZACIÓN DEL TRABAJO Y MIGRACIÓN: UNA REVISIÓN DE LA LITERATURA INTERNACIONAL

Guilherme Primo Matias, Gabrielle Ribeiro Rodrigues da Silva, Fabio Emanuel Farago

Universidade Federal do Paraná - UFPR, Paraná, (Brasil)

Universidade de São Paulo - USP, São Paulo, (Brasil)

\section{HISTORIA DEL ARTÍCULO}

Historia del Artículo:

Recibido: 15 Febrero 2019

Aceptado: 01 Noviembre 2019

Disponible en línea: 01 de enero 2020

Double Blind Review System

Editor Científico

Ilan Avrichir

Palabras-clave:

Trabajo precario

Proceso de migración

Precarización. Obrero

Revisión sistemática

\begin{abstract}
RESUMO
Objetivo: Esta pesquisa tem como objetivo destacar a relação entre precarização do trabalho e migração, com base no entendimento de que os trabalhadores migrantes são participantes no processo de desenvolvimento econômico e social dos países.

Método: A metodologia utilizada foi uma revisão sistemática da literatura internacional sobre trabalho precário e migração no período de 2008 a 2018. Principais resultados: As pessoas migram entre países por fatores econômicos, sociais ou políticos. Comum dessas três razões é o desejo de ter melhores condições de vida. Mesmo em alguns casos, esses migrantes têm acesso a benefícios, provavelmente sofrerão algum tipo de precariedade - seja em serviços insalubres, sem proteção legal ou vivendo em moradias inadequadas. Essa é a natureza ambivalente do trabalho precário - e suas consequências. Relevância/originalidade: Observa-se que grande parte da pesquisa sobre migração nos países menos desenvolvidos começou com proposições emprestadas de pesquisadores que codificaram a experiência dos países desenvolvidos. É necessário em nosso campo apresentar um exame sistemático de como a precarização e a migração são abordadas nos estudos organizacionais.

Contribuições teóricas/metodológicas: Como contribuição para o campo, neste artigo é proposto um modelo teórico que envolve os dois fenômenos e fornece ao leitor informações científicas padronizadas e sistemáticas que podem auxiliar no desenvolvimento do campo, mapeando o conhecimento existente nesse assunto.
\end{abstract}

\section{Cite it like this:}

Matias, G., Silva, G., \& Farago, F. (2020). Precarization of Work and Migration: A Review of the International Literature. Internext, 15(1), 19-36. doi: http://dx.doi.org/10.18568/internext.v15i1.527 